Tropical Journal of Pharmaceutical Research June 2018; 17 (6): 1061-1066

ISSN: $1596-5996$ (print); 1596-9827 (electronic)

(C) Pharmacotherapy Group, Faculty of Pharmacy, University of Benin, Benin City, 300001 Nigeria.

\title{
Assessment of activity and mechanism of action of $\beta-D-$ glucan against dengue virus
}

\author{
Yonghong Song ${ }^{1}$, Wenzhi Zhang ${ }^{2}$, Ravindran Jaganathan ${ }^{3 *}$ \\ ${ }^{1}$ Department of Anatomy, Medical College, Hebei University of Engineering, Congtai Street 83, Handan 056002, Hebei \\ Province, China, ${ }^{2}$ Innoscience Research Sdn Bhd, Suites B-5-7, Level 5, Sky Park @ One City, Jalan USJ 25/1, 47650 Subang \\ Jaya, Selangor, ${ }^{3}$ Pathology Unit, Lab Based Dept., Faculty of Medicine, Universiti Kuala Lumpur-Royal College of Medicine \\ Perak (UniKL-RCMP), No. 3 Jalan Greentown, Ipoh-30450, Perak, Malaysia
}

*For correspondence: Email: jravimicro@gmail.com; Tel: +60-176184663

Sent for review: 13 August 2017

Revised accepted: 14 May 2018

\begin{abstract}
Purpose: To assess the antiviral efficiency of $\beta$-D-glucan (BDG) on human liver cell line (WRL68) infected with dengue virus (DENV).

Methods: Cytotoxic activity was assessed via 3-(4,5-dimethylthiazol-2-yl)-2,5-diphenyltetrazolium bromide (MTT) assay. Solid-phase virus binding assay was used to determine the presence of a chemical affinity between dengue virus type 2 (DENV-2) and BDG. Plaque formation assay was performed to measure the suppression of DENV-2.

Results: Plaque formation assay results revealed that the inhibition of DENV infection by BDG was effective at $400 \mu \mathrm{g} / \mathrm{mL}$ which occurred by inhibiting virus replication. BDG inhibited DENV replication and produced minimal toxicity on WRL68 cells at $600 \mu \mathrm{g} / \mathrm{mL}$ in a concentration-dependent manner. Treatment of DENV-2 with the highest concentration of the BDG resulted in 60,55 , and $50 \%$ viability at 24,48 , and $72 h$, respectively. Plaque formation and binding efficiency data confirmed that BDG protected the WRL68 cells against DENV-2.

Conclusion: The results indicate that in infected cells, $\beta$-D-glucan was found to be potent in inhibiting replication of the dengue virus.
\end{abstract}

Keywords: Dengue, $\beta$-D-glucan, Polysaccharide, Antiviral, Plaque formation, Binding efficiency

\begin{abstract}
This is an Open Access article that uses a funding model which does not charge readers or their institutions for access and distributed under the terms of the Creative Commons Attribution License (http://creativecommons.org/licenses/by/4.0) and the Budapest Open Access Initiative (http://www.budapestopenaccessinitiative.org/read), which permit unrestricted use, distribution, and reproduction in any medium, provided the original work is properly credited.

Tropical Journal of Pharmaceutical Research is indexed by Science Citation Index (SciSearch), Scopus, International Pharmaceutical Abstract, Chemical Abstracts, Embase, Index Copernicus, EBSCO, African Index Medicus, JournalSeek, Journal Citation Reports/Science Edition, Directory of Open Access Journals (DOAJ), African Journal Online, Bioline International, Open-J-Gate and Pharmacy Abstracts
\end{abstract}

\section{INTRODUCTION}

Dengue is a transmittable fastidious disease caused by four different types of dengue viruses (DENV1, DENV-2, DENV-3 and DENV-4), is spread by mosquito bite. DENV is an RNA virus belonging to family Flaviviridae and genus Flavivirus. In humans, DENV is transmitted by the mosquito of female Aedes. The virus is widely spread in the tropical and subtropical regions; however, the entire global human population is at risk [1]. Malaysia accounts for approximately $3.6 \%$ of the fatality rate of DENV infections [2]. Most deaths resulting from DENV infections occur after the following sequence of stages: mild infection, severe haemorrhagic fever, and shock syndrome [3].

Patients with DENV infection usually present with no symptoms or few clinical symptoms. The 
clinical symptoms include abdominal pain, fluid accumulation, vomiting, and liver enlargement with a simultaneous decrease in platelet count. Severe forms of DENV infections result in haemorrhage or organ dysfunction [4]. DENVs can multiply rapidly and produce dangerous cytopathogenic effects (CPEs) in various types of liver cell lines [5]. DENVs adversely affect hepar's activity, showed by hepatomegaly, aberration of enzyme in liver cells, hepatic breakdown, and histological alterations [6-9].

BDG is also known as an immunomodulator or biological response modifier. Glucans are naturally occurring polysaccharides formed through combination of bioactive molecules. The preserved form of glucans consists of glucose molecules and diverse carbohydrates which also make up the cell wall's structural constituents [10]. The biological properties of glucans have been well documented. They have been documented to potentiate immunity, prevent the proliferation of cancer cells, and reduce stress, and reduce cholesterol levels [11]. In a swine model, glucans have also been shown to be effective against influenza infection [12].

Despite the identification of numerous cases of DENV infections and their severity, no treatment options and vaccines are currently available to treat these infections. Hence, recognising the signs and providing necessary treatment options are crucial steps for reducing the risk of death [13]. Proteins that are necessary in the DENV life cycle can be assumed to be potent therapeutic agents for vaccine development; this could be an effective method for discovering the bioactive constituents against the virulence of flaviviruses [14]. Thus, this research was aimed to investigate the antiviral activity of BDG in human liver cells (WRL68) infected with DENV.

\section{EXPERIMENTAL}

\section{Cell culture and viruses}

The human hepatic cell line WRL68 was obtained from American Type Culture Collection (ATCC) and cultured in the Department of Anatomy, Medical College, Hebei University of Engineering, China. The cell line was subcultured in a $5 \% \mathrm{CO}_{2}$ incubator and sustained at $37^{\circ} \mathrm{C}$. Before performing the experiment, the cells were plated in 24-well plate at $3 \times 10^{3}$ cells/well in $0.2 \mathrm{~mL}$ of a Roswell Park Memorial Institute 1640 medium solution (1 \% penicillin-streptomycin and $10 \%$ fetal bovine serum) and were incubated for $24 \mathrm{~h}$ in $\mathrm{a} \mathrm{CO}_{2}$ incubator at $37^{\circ} \mathrm{C}[15]$.
DENV-2 strain was obtained from ATCC® VR$24^{\mathrm{TM}}$ and cultured in human liver cells (WRL68) and the viral titers were affirmed through cellular cytopathogenic effect observation. The viral stock was kept at $-80^{\circ} \mathrm{C}$ till further need.

\section{BDG stock preparation}

Dimethyl sulfoxide (DMSO) was used to dilute BDG (Sigma-Aldrich, USA) to prepare a stock concentration $(1 \mathrm{mg} / \mathrm{mL})$ and kept at $-20^{\circ} \mathrm{C}$ till further need.

\section{Assessment of cytotoxicity}

Cells were plated at a concentration of $1 \times 10^{5}$ cells $/ \mathrm{mL}$ in 96-well plates. The 3-(4,5dimethylthiazol-2-yl)-2,5-diphenyltetrazolium bromide (MTT) assay was quantitatively carried out through colorimetric detection. The seeded cells were incubated at $37^{\circ} \mathrm{C}$ for $24 \mathrm{~h}$ until subconfluence was observed. Different amounts of BDG were added (to obtain the concentration range $100-600 \mu \mathrm{g} / \mathrm{mL}$ ) and incubated for $72 \mathrm{~h}$ after the growth medium was removed. Fifty $\mu \mathrm{L}$ thiazolyl blue tetrazolium bromide solution (Sigma-Aldrich, USA) was added to the cell culture and incubated for $2-4 \mathrm{~h}$. The resulting formazan was diluted in DMSO and quantified at $490 \mathrm{~nm}$. The cytotoxic concentration at which the compound can cause death in $50 \%$ of the viable cells in the host was determined using concentration-response curves based on absorbance $(A)$ as in Eq 1.

Cell viability $(\%)=(\mathrm{At} / \mathrm{Au}) 100$

where At and Au are the absorbance of treated and untreated cells, respectively.

\section{Solid-phase virus binding assay}

The chemical attraction among BDG and DENV2 was assessed through the solid-phase virusbinding assay [16] with minor modifications. Phosphate-buffered BDG was immobilised overnight on microfibre plates. The plates were blocked with phosphate-buffered saline (PBS) comprising $5 \%$ bovine serum albumin and incubated at $28^{\circ} \mathrm{C}$ for $2 \mathrm{~h}$ with a solution of purified virus (5 $\mu \mathrm{g} / \mathrm{well})$. The plates were washed with anti-DENV human antiserum, and then with HRP-conjugated anti-human immunoglobulin. Then, the plates were incubated for $1 \mathrm{~h}$ at $28^{\circ} \mathrm{C}$. The complexes formed were detected after o-phenylenediamine incubation. BDG without purified virus was used as control in this test. The optical density reading was taken at $492 \mathrm{~nm}$. 


\section{Plaque reduction assay}

Plaque reduction assay (PRA) was used to measure the antiviral activity of BDG [17]. The confluent WRL68 cell line was infected with DENV-2 for $2 \mathrm{~h}$. Later, the cells were rinsed twice using PBS and coated with $1.2 \%$ agarose at 42 - $45{ }^{\circ} \mathrm{C}$, containing Dulbecco modified eagle medium with BDG at different concentrations then incubated for 2-5 days. The fixative used was $10 \%$ formalin, and $1 \%$ crystal violet solution was used to stain the cells. Number of plaque was manually counted while viral inhibition was determined as in Eq 2.

Viral inhibition $(\%)=\{(\mathrm{Npv}-\mathrm{Npt}) / \mathrm{Npv}\} 100$

where $\mathrm{Npv}$ is the number of plaque virus and $\mathrm{Npt}$ is Number of plaque tested.

\section{Statistical analysis}

Statistical analysis was determined using the SPSS 13.0 software. Tukey's multiple comparison tests was utilized to contrast with varying treatments, and the significance level was fixed at $p<0.05$. The outcomes were exerted as mean \pm standard deviation $(n=3)$.

\section{RESULTS}

\section{Cellular toxicity}

The toxicological effects of BDG were determined using the MTT proliferation experiment. Figure 1 shows that the proliferation of the WRL68 cells remains unaffected in the presence of BDG; hence the cytotoxic effect of $\mathrm{BDG}$ is minimal.

The cytotoxicity of BDG in the WRL68 cells was evaluated at varying concentrations in the range $100-600 \mu \mathrm{g} / \mathrm{mL}$ for 24,48 , and $72 \mathrm{~h}$. The cytotoxic effects of BDG on the WRL68 cells increased with the time of exposure and concentration.

The cells treated with the highest concentration of BDG $(600 \mu \mathrm{g} / \mathrm{mL})$ for 24,48 , and $72 \mathrm{~h}$ exhibited 50, 55 and $60 \%$ cell viability, respectively. From Figure 1, BDG exhibited dose-dependent cell toxicity and reduced the cell viability in the WRL68 cells. The time-dependent cell toxicity observed at $72 \mathrm{~h}$ displays the lowest cell viability at varying concentrations $(0,100$, $200,300,400,500$ and $600 \mu \mathrm{g} / \mathrm{mL}$ ) of BDG.

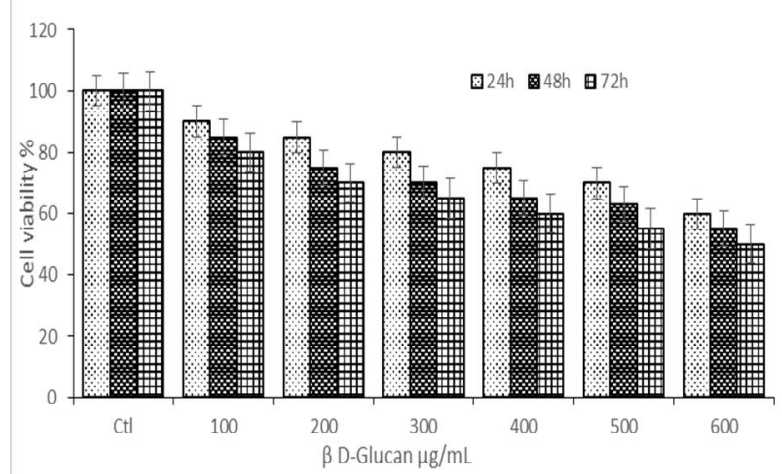

Figure 1: Assessment of the cytotoxicity of BDG

\section{Inhibitory effects of BDG on DENV-2 in the WRL68 cells}

BDG exhibited a strong antiviral activity when incubated with virus-infected cells. BDG inhibited viral activity at different concentrations. The strongest antiviral effect was exhibited at the concentration of $400 \mu \mathrm{g} / \mathrm{mL}$. The measurement of antiviral activity at different time intervals (24, 48 , and $72 \mathrm{~h}$ ) also exhibited the best effect at the concentration of $400 \mu \mathrm{g} / \mathrm{mL}$ as shown in Figure 2. Hence, $400 \mu \mathrm{g} / \mathrm{mL}$ of $B D G$ is the optimal concentration exhibiting strong antiviral effect on DENV.

$24 h$

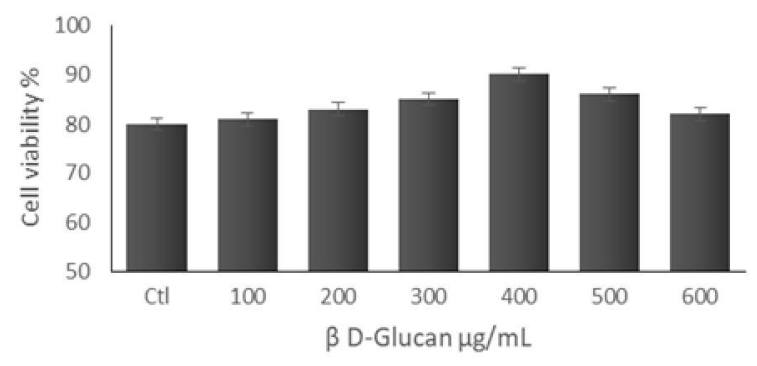

$48 \mathrm{~h}$

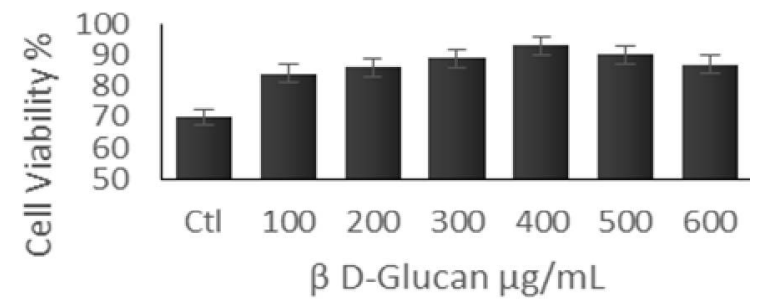

Figure 2: The antiviral activity of BDG on DENV-2 (MTT assay)

\section{Affinity between DENV-2 and BDG}

The chemical affinity between DENV-2 and BDG was assessed via the solid-phase virus-binding assay. The control, only BDG (in absence viral extract) and BDG with the viral extract were immobilized in a microtitre plate and treated with 
human anti-DENV serum and measured at a wavelength of $492 \mathrm{~nm}$. Aberrant readings were detected in the control wells, whereas the other wells (containing BDG with the viral extract) exhibited an absorbance of 0.32 . The binding assay results indicate that $B D G$ binding to DENV-2 may be liable for the inhibitory effects of BDG.

\section{Assessment of antiviral effects of BDG by PRA}

We observed a significant difference among different doses of incubation with the infected cell line. On post-infection day 5, in the control, the DENV plaques overlay each other; hence, counting the number of plaques was difficult. The BDG-treated plaques were countable. The DENV-2 serotypes exhibited different size and plague morphology. Under optimised PRA conditions, all the plaques were easily counted. This experiment demonstrates a linear relationship between virus and BDG. At 400 $\mu \mathrm{g} / \mathrm{mL}$, BDG showed least plaque production, which implied the maximum inhibition rate (Figure 3). The reduction in plaque number established that BDG exhibited DENV-2 neutralisation activity.

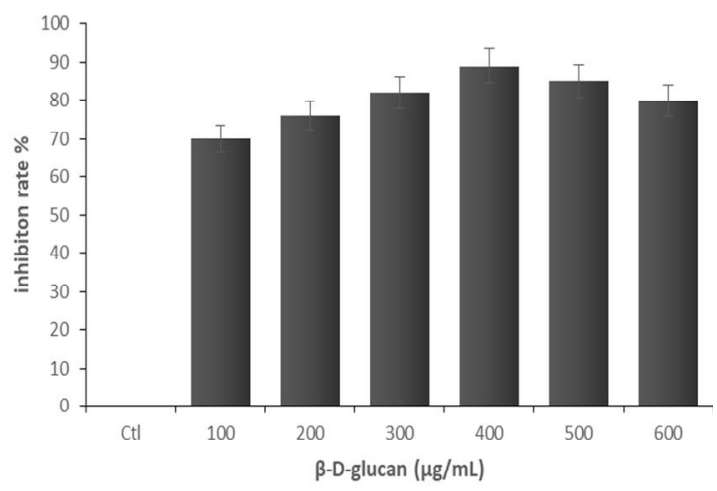

Figure 3: Antiviral activity of BDG measured through plaque formation assay

\section{DISCUSSION}

Drugs that can act towards DENV emphasizes the prospect to stop and decrease the severity of DENV infections. An anti-DENV drug should meet several necessities, for example it should have an intact profile, no toxicity, a convenient route for administration, stability, a long shelf life, and a low price. The drug should be effective towards different types of DENV in both symptomatic and asymptomatic infections [18]. Therefore, the demand for DENV-specific antiviral drugs is high, and the development of these drugs is prioritized. Developing such antiviral drugs might enable worldwide prevention of DENV infections. Glucans can boost immunity, and they are found to be highly potent against bacteria and viruses [19].

BDG pre-treatment enhanced the activity of leucocytes in patients with DENV infections [20]. BDG pre-treatment was likewise found to decrease the occurrence of pneumonia, and BDG acts against bacterial infections exerting a bacteriostatic and bactericidal effect on Escherichia coli and Staphylococcus aureus, respectively.

The polysaccharide BDG can also inhibit herpes simplex virus-1. BDG can stimulate natural killer cells; hence, it acts as an effective antiviral agent [21].The disparity effects of BDG in inhibiting the replication of DENV2 were determined using the MTT, solid-phase binding, and plaque neutralization assays. The concentration and time dependent effects of BDG suggest that the capacity of BDG against DENV is higher than the activities of therapeutic drugs. Deviations in cell viability often result from degenerative changes known as CPE, which occur at long exposure times and high doses, as in the case of 600 $\mu \mathrm{g} / \mathrm{mL}$ BDG.

The MTT assay depends on the conversion of tetrazolium salts into formazans. The test is easy to execute, highly accurate, and reliable despite some minor limitations in the presence of metabolic disturbances.

High cell mortality was observed when cells of the human liver cell line WRL68 were infected with DENV. Extend of cell destruction differs with viral species and cell lines; and it is determined using the MTT assay at an absorbance of 490 $\mathrm{nm}$. Some virus populations cause few or no CPEs, while others can destroy the entire cell population. The characteristics of DENV-2 can be observed by routine analysis of cultures. Infected cells treated with BDG at $400 \mu \mathrm{g} / \mathrm{mL}$ exhibited an increase in cell viability, whereas those cells treated with $600 \mu \mathrm{g} / \mathrm{mL}$ reduced the number of viable cells, which might be due to the CPE of BDG itself.

At $400 \mu \mathrm{g} / \mathrm{mL}$, BDG showed antiviral activity against DENV-2 infected cells, which is consistent with earlier findings [22]. The polysaccharide was reported to effectively inhibit the replication of DENV [17].

The solid-phase binding assay, which is used to identify specific in-vitro protein-protein interactions, is a sensitive method that requires the use of specific antigen and antibodies [23]. The use of entry inhibitors of enveloped viruses 
might be an effective strategy for therapeutic intervention. Since the inhibitor acts extracellularly, it facilitates access and limits cell toxicity [24]. Previously polysaccharides have been reported to possess antiviral effects on DENV via attaching to the viral substance [17]. In this current research, BDG was found to bind strongly to the viral supernatant; the binding might be due to its antiviral activity.

Natural polysaccharides that are structurally similar to heparin sulfate (HS), the receptor molecule of DENV-2 [25], are powerful inhibitors of DENV infection [26]. Structurally similar polysaccharides tend to compete with $\mathrm{HS}$ for the binding site on DENV-2, thus preventing DENV-2 from entering into the cell [27]. Large-scale clinical trials are being conducted worldwide to diagnose DENV infections. Therefore, identifying a reliable anti-DENV drug, evaluating its immune response, and assessing its antiviral activity are crucial steps in preventing the spread of DENV infections.

However various tests are available to evaluate immunological responses, a difference was observed in their sensitivity and specificity, as seen in the haemagglutination inhibition assay [28]. The complement fixation test is highly specific to DENV infections, and it requires an easily available DENV-specific immunoglobulin [29]. ELISA performed for dengue is not specific for a serotype, because it is only a measure of the capacity of an antibody to bind to DENV and not the capacity to neutralize DENV. Hence, the PRA is considered the golden standard for measuring antibodies that neutralize the DENV [30].

The PRA results of BDG at $400 \mu \mathrm{g} / \mathrm{mL}$ shows a more significant reduction in the percentage of plaque counts with other concentrations and against untreated infected cell. BDG might function act as an effective antiviral drug by directing virus synthesis-related proteins that are involved in the replication cycle. BDG markedly inhibits the replication of the DENV in the WLR68 cells. Previous studies have revealed that various parts and extracts of medicinal plants are useful for treating DENV infections. However, unexplored plants might also contain numerous therapeutic substances. Hence, this creates the necessity to develop new therapeutic anti-DENV drugs with low cytotoxicity. Therefore, BDG may act as a potent therapeutic drug target against various stereotypes of DENV. Target-specific action of a drug at appropriate stages of virus lifecycle might facilitate in preventing the spread of viral infections, and it might also provide insights on crucial areas of DENV research in the near future.

\section{CONCLUSION}

The findings of this study indicate that administering BDG treatment to patients with DENV infections at the appropriate time and stage can protect the cells against DENV infections and inhibit viral replication. The mechanism by which BDG inhibits replication and protects against DENV requires further exploration. Thus, BDG may serve as an effective immunomodulatory agent against DENV infection and replication.

\section{DECLARATIONS}

\section{Conflict of Interest}

No conflict of interest associated with this work.

\section{Contribution of Authors}

The authors declare that this research was conducted by them and all accountabilities concerning to the contents of this manuscript will be endured by the authors.

\section{REFERENCES}

1. Chen R, Vasilakis N. "Dengue-Quo Tu et Quo Vadis?" Viruses 2011; 3: 1562-1608.

2. Beatty ME, Stone A, Fitzsimons DW, Hanna JN, Lam SK, Vong S, Guzman MG, Mendez-Galvan JF, Halstead SB, Letson GW. Best practices in dengue surveillance: a report from the Asia-Pacific and Americas Dengue Prevention Boards. PLoS Negl Trop Dis 2010; 4: e890.

3. Murphy BR, Whitehead SS. "Immune response to dengue virus and prospects for a vaccine". Ann Rev Immunol 2011; 29: 587-619.

4. OMS. Dengue: Guidelines for Diagnosis, Treatment, Prevention and Control, new edition. France; WHO Press, World Health Organization, 20 Avenue Appia, 1211 Geneva 27, Switzerland, 2009.

5. Lin YL, Liu CC, Lei HY, Yeh TM, Lin YS, Chen RMY, Liu HS. Infection of five human liver cell lines by dengue-2 virus. J Med Virol 2000; 60: 425-431.

6. Mohan B, Patwari AK, Anand VK. Hepatic dysfunction in childhood dengue infection. J Trop Pediatr 2000; 46: 40-43.

7. Wahid SF, Sanusi S, Zawawi MM, Ali RA. A comparison of the pattern of liver involvement in dengue hemorrhagic fever with classic dengue fever. Southeast Asian J Trop Med Public Health 2000; 31: 259-263.

8. Subramanian $V$, Shenoy $S$, Joseph AJ. Dengue hemorrhagic fever and fulminant hepatic failure. Dig Dis Sci 2005; 50: 1146-1147. 
9. Bhamarapravati N. Hemostatic defects in dengue hemorrhagic fever. Rev Infect Dis 1989; 11: S826S829.

10. Vetvicka, editor. $\beta$-Glucans as Natural Biological Response Modifiers. New York: Nova Science Publishers; 2013a.

11. Vetvicka V, Novak M, editors. Biology and Chemistry of Beta Glucan, Vol. 2, Beta-glucan, Structure, Chemistry and Specific Application. Oak Park: Bentham Science Publisher; 2013b.

12. Jung K, Ha Y, Ha SK, Han DU, Kim DW, Moon WK, Chae C. Antiviral effect of Saccharomyces cerevisiae beta-glucan to swine influenza virus by increased production of interferon-gamma and nitric oxide. $J$ Vet Med B Infect Dis Vet Public Health 2004; 51: 72-76.

13. FUNASA. Dengue: Diagnóstico E Manejo Clínico. Ministério da Saúde, Fundação Nacional da Saúde, Setor de Autarquias Sul Quadra 4, Brasília, Brazil; 2002.

14. Ruzek D. Flavivirus Encephalitis. In: Smith D, editor. Encephalitic Flaviviruses. 2011. $1 \mathrm{p}$.

15. Krishnegowda G, Hajjar AM, Zhu J, Douglass EJ, Uematsu S, Akira S, Woods AS, Gowda DC. Induction of proinflammatory responses in macrophages by the glycosylphosphatidylinositols of Plasmodium falciparum. J Biol Chem 2005; 280: 8606-8616.

16. Hidari KIPJ, Takahashi N, Arihara M, Nagaoka M, Morita $K$, Suzuki T. "Structure and anti-dengue virus activity of sulfated polysaccharide from a marine alga". Biochem Biophy Res Com 2008; 376: 91-95.

17. Martin NC, Pardo J, Simmons M, Tjaden JA, Widjaja S, Marovich MA, Sun W, Porter KR, Burgess TH. An immunocytometric assay based on dengue infection via DC-SIGN permits rapid measurement of anti-dengue neutralizing antibodies. J Virol Methods 2006; 134: 74 85.

18. World Health Organization. Dengue: guidelines for diagnosis, treatment, prevention and control, new edition. France: WHO Press; 2009. $147 p$.

19. Chang ST, Wasser SP. The role of culinary-medicinal mushrooms on human welfare with a pyramid model for human health. Int J Med Mushrooms 2012; 14:95-134.

20. Suzuki I, Hashimoto K, Ohno N, Tanaka H, Yadomae $T$. Immunomodulation by orally administered beta-glucan in mice. Int J Immunopharmacol 1989; 11: 761-769.
21. Marchetti M, Pisani S, Pietropaolo V, Seganti L, Nicoletti $R$, Degener $A$, Orsi $N$. Antiviral effect of a polysaccharide from Schlerotium glucanicum towards herpes simplex virus type 1 infection. Planta Med 1996; 62: 301-307.

22. Talarico LB, Pujol CA, Zibetti RG, Faría PC, Noseda MD, Duarte ME, Damonte EB. The antiviral activity of sulfated polysaccharides against dengue virus is dependent on virus serotype and host cell. Antiviral Res 2005; 66: 103-110.

23. Ono L, Wollinger $W$, Rocco IM, Coimbra TL, Gorin PA, Sierakowski MR. In vitro and in vivo antiviral properties of sulfated galactomannans against yellow fever virus (BeH111 strain) and dengue 1 virus (Hawaii strain). Antiviral Res 2003; 60: 201-208.

24. Arlinghaus FT, Eble JA. The collagen-binding integrin alpha2 beta1 is a novel interaction partner of the $T$. flavoviridis venom protein flavocetin- $A$. J Biol Chem 2012; 288: 947-955.

25. de S.F-Tischer PC, Talarico $L B$, Noseda MD, Guimarães $S M P B$, Damonte EP, Duarte MER. "Chemical structure and antiviral activity of carrageenans from Meristiella gelidium against herpes simplex and dengue virus". Carbohydrate Polymers 2006; 63: 459-465.

26. Teissier E, Penin F, Pécheur El. "Targeting cell entry of enveloped viruses as an antiviral strategy". Molecules 2011; 16: 221-250.

27. Acosta EG, Talarico LB, Damonte EB. "Cell entry of dengue virus". Future Virology 2008; 3: 471-479.

28. Talarico $L B$, Damonte EB. "Interference in dengue virus adsorption and uncoating by carrageenans." Virol 2007; 363: 473-485.

29. Clarke DH, Casals J. Techniques for hemagglutination and hemagglutination-inhibition with arthropod-borne viruses. Am J Trop Med Hyg 1958; 7: 561-573. [PubMed]

30. Innis BL, Nisalak A, Nimmannitya $S$, Kusalerdchariya $S$, Chongswasdi V, Suntayakorn S, Puttisri P, Hoke CH. An enzyme-linked immunosorbent assay to characterize dengue infections where dengue and Japanese encephalitis co-circulate. Am J Trop Med Hyg 1989; 40: 418-427. 